\title{
The English Reading Habits of English Language Education Undergraduate Students at English Department
}

\section{Kebiasaan Membaca Teks Berbahasa Inggris Mahasiswa Pendidikan Bahasa Inggris di Jurusan Sastra Inggris}

\author{
Windha Aestetika Wulandari, Utari Praba Astuti*, Furaidah \\ Universitas Negeri Malang, Jl. Semarang No. 5 Malang, Jawa Timur, Indonesia \\ *Penulis Korespondensi, Surel: utari.praba.fs@um.ac.id
}

Paper received: 02-06-2021; revised: 14-06-2021; accepted: 30-06-2021

\begin{abstract}
Good reading habits help comprehension and logic because they can empower us to absorb material analytically, critically, and reflectively. However, the technique for encouraging an interest in reading, particularly in schools and universities, has not obtained the best outcomes. In this case, family, community, and educational institutions simultaneously play a significant role in promoting English Foreign Language students' enthusiasm for reading. Therefore, the aim of this study is to determine ELE undergraduate students' reading habits in English Department, Universitas Negeri Malang. This type of research used descriptive qualitative. The data collection technique used was a questionnaire and distributed via Google form. The questionnaire elicited students' attitudes towards reading, purpose of reading, reading frequency, and reading preferences. The results showed that most of the ELE undergraduate students have a high reading habit. However, students' reading habits still need to be improved. It is shown that the students like reading as an indispensable part of their lives because of the reading treatment they get from an early stage of age. It makes them have a positive attitude towards reading, they also have a purpose for reading, and increase their reading preferences. Furthermore, they also need to increase their frequency of reading practice and the number of books read.
\end{abstract}

Keywords: reading habits, English Language Education (ELE)

\begin{abstract}
Abstrak
Kebiasaan membaca yang baik dapat membantu pemahaman dan logika karena dapat memudahkan untuk menerima materi secara analitis, kritis, dan reflektif. Namun, teknik yang digunakan untuk mendorong minat membaca, khususnya di sekolah dan universitas, masih belum mendapatkan hasil yang terbaik. Dalam hal ini, keluarga, masyarakat, dan lembaga pendidikan secara bersamaan memiliki peran penting dalam mendorong minat membaca Bahasa Inggris siswa. Oleh karena itu, tujuan dari penelitian ini adalah untuk mengetahui bagaimana kebiasaan membaca mahasiswa Jurusan Bahasa Inggris Universitas Negeri Malang. Jenis penelitian yang digunakan adalah deskriptif kualitatif. Teknik pengumpulan data yang digunakan adalah kuesioner dan disebarluaskan melalui google form. Kuesioner tersebut membahas sikap siswa terhadap membaca, tujuan membaca, frekuensi membaca, dan preferensi membaca. Hasil penelitian menunjukkan bahwa sebagian besar mahasiswa jurusan pendidikan Bahasa Inggris memiliki kebiasaan membaca yang tinggi. Namun, kebiasaan membaca siswa masih perlu ditingkatkan lagi. Terlihat bahwa siswa menyukai membaca, karena sebagai bagian yang tak terpisahkan dari kehidupan karena mereka telah dilatih membaca sejak usia dini. Oleh karena itu, mereka memiliki sikap positif terhadap membaca, mereka juga memiliki tujuan untuk membaca, dan meningkatkan preferensi membaca mereka. Selain itu, mereka juga perlu meningkatkan frekuensi latihan membaca dan jumlah buku yang dibaca.
\end{abstract}

Kata kunci: kebiasaan membaca, Pendidikan Bahasa Inggris 


\section{Introduction}

The world of education is closely connected to literacy activities, particularly reading. Reading is a key that must be owned for the future, not merely for successful learning in the classroom. Reading is an important activity that is inextricably linked to academics' roles, such as students gaining critical thinking from reading. This is due to the fact that the fundamental process of learning is reading. It is the process of understanding and acquiring knowledge for the purpose of personal development and growth. Reading English is commonly considered the most important skill in nations where English is studied as a foreign language, such as Indonesia.

Since English is a foreign language in Indonesia, it is also possible that English language students will have trouble understanding what they are reading. When it comes to reading, Indonesia is still far behind other developed countries. This argument is drawn from the results of a UNESCO study published in 2013, which indicated that a comparison of reading interest per individual in Indonesia revealed that one person who reads is equal to a thousand people who do not. This shows that Indonesians' reading habits are still quite poor (Antari, Nenden, Neneng 2016). Due to the importance of reading text in improving students' reading skills, these difficulties in reading text should be identified and resolved by both the students and the teacher, as the difficulties will have a negative impact on the students' ability and motivation to meet the reading goal.

There are certain factors which are found to actively contribute to the development of reading habits. Internal and external factors have a huge impact on students' reading habits. Triatma (2016) confirms that there are two elements that influence reading interest: internal factors such as emotion, attention, and motivation, and external factors such as lecturers' role, environment, and facilities. The students' lack of interest in reading derives from internal factors. This is due to the state of the Indonesian people, who had never read before and were more likely to listen orally before the emergence of telecommunications, informatics, and broadcasting technology. As a result, many Indonesian people would rather watch television than reading. Previous studies about reading habits have been conducted by Noor (2011) he conducted a study on the reading habits and preferences of English Foreign Language (EFL) postgraduate students at National University of Malaysia. This study examined the type of reading material chosen, the reasons for reading, and the language chosen for reading. From these studies, the research revealed that postgraduate students still need extensive programs which will enable them to explore their literacy development. This situation can be much worse if parents keep ignorant about the awareness of reading activities because they are busy working and no longer have enough time. In line with this study, therefore, students should be motivated and help to read various types of texts in the language as part of the compulsory and elective courses.

As a result, the Indonesian government has made English one of the compulsory subjects from elementary school through university. Various reading campaigns in the community, such as Gerakan Indonesia membaca (GIM), Gerakan Literasi Bangsa (GLB), and Gerakan Literasi Sekolah (GLS) were initiated during the President Joko Widodo's government. Based on the Department of English catalogue from the 2019/2020 academic year at English Language Education in Universitas Negeri Malang, students are introduced to Intensive reading, Basic reading, Intermediate reading, Advanced reading, and Extensive reading. They are frequently engaged with English-language texts or various topics. Iftanti (2012) also supported that 
external factor such as a health literacy environment can help to cope the students lack of reading habits with the parents reading aloud, great literary works, and good reading habits in L1 influence EFL students' reading motivation. In this context, for students to develop a good reading habit, they must have supportive and conducive circumstances, whether it is their immediate surroundings or their reading preferences. Another previous study is web-based study on freshmen's reading habits and their attitude toward reading within the English Department Universitas Negeri Malang conducted by Zulkarnain (2019). It appeared from the indicators that the students have numerous sorts of material being read, frequency of reading, the average time spent on reading, the freshmen's clear reading goals, and freshman's attitude toward reading. From the data that have been collected, it can be concluded that students of the English department program have great reading habits. The easy access to digital media is a big challenge for reading habits. It gives an impact for everyone. Students, without a doubt, require technology in the form of the internet in order to communicate, discuss, and process information at the same time. Their familiarity with technology, such as smartphones or tablets, leads them to prefer digital devices to printed documents. Furthermore, it is a modern reading habit in which EFL students favor internet-based reading over paper-based reading (Shen, 2006).

Based on the previous studies, there are certain factors that are found to actively contribute to the development of reading habits. Personal characteristics of the students from internal factors, such as emotion, attention, and motivation. Moreover, the environmental influence from external factors, such as parental influence, peer pressure, school curriculum, and teachers are the other factors that can either support or militate against better reading habits. This research discusses a study intended to investigate the English reading habits of English Language Education students. It also seeks to find out the students' attitude towards reading, the students' purposes of reading English texts, the students' frequency in reading English text, and students' preference in reading English text. Thus, considering the explanation, this paper focused on answering the following research questions: How are the English reading habits of English Language Education undergraduate students at English Department, Universitas Negeri Malang?

\section{Method}

In this research, the researcher utilizes a survey as the method for gathering the data. The research design of this research is descriptive design with a quantitative approach and survey as a method to collect the data. Sugiyono (2009) added, descriptive research design used to describe the data that has been collected as it is. Lestari, Latief, and Widiati (2015) also explained survey research is commonly used to describe the opinions, attitudes, preferences, and perceptions of people's interest.

The researchers used a questionnaire to get the data of this research. In selecting the items of the questionnaire, the researcher had consulted the expert. The statements from four indicators are adapted from two previous studies which are from Gaona and Villuendas (2011) and Putra (2018). The researcher decided to adapt the questionnaire from the two previous research because it followed the general design, then the researcher added some items and substantially changed some items.

The questionnaire was distributed to the students starting from 9th of November until 30thof November 2020 via Google form. The questionnaire was made online so that the 
students could respond to it easily, anytime and anywhere. From 121 total respondents from the fifth semester, only 91 respondents gave the feedback. There are a few things beyond the control of the researcher which come about only 91 respondents who succeeded in giving their interest. The most important factors are: 1). The questionnaire was distributed online during pandemic. 2). Questionnaires were distributed close to the final exam semester so that the focus of the respondents was divided. The link of the questionnaire was distributed through personal WhatsApp group chats that they have with other students from the same semester.

The survey used in this study is a closed-ended questionnaire. The questionnaire in this research used modification Likert scale of 1-4. The scale used were, 1: Strongly disagree, 2: Disagree, 3: Agree, 4: Strongly Agree. The questionnaire consists of four indicators. The indicators are attitude towards reading, purpose on reading, frequency on reading, and reading preference. The research procedure begins with the researcher (1) identifying the topic, (2) developing the research question, (3) adapting the questionnaire from the previous study, (4) testing the questionnaire to the selected respondents, and (5) analyzing and interpreting the results.

\section{Results and Discussion}

\subsection{Results}

\subsubsection{Attitudes towards Reading}

Table 1. Result of Students' Attitudes Towards Reading

\begin{tabular}{clcccc}
\hline No. & \multicolumn{1}{c}{ Statements } & $\begin{array}{c}\text { Strongly } \\
\text { Agree }\end{array}$ & Agree & Disagree & $\begin{array}{c}\text { Strongly } \\
\text { Disagree }\end{array}$ \\
\hline 1. & Reading is & 46 & 37 & 6 & 2 \\
& Enjoyable & $(50.5 \%)$ & $(40.6 \%)$ & $(7 \%)$ & $(2.2 \%)$ \\
$2 . \quad$ & Reading books is & 45 & 29 & 14 & 3 \\
& interesting activity & $(49.5 \%)$ & $(31.8 \%)$ & $(15.4 \%)$ & $(3.3 \%)$ \\
3. $\quad$ Ilike borrowing & 48 & 28 & 8 & 7 \\
& books from library & $(52.8 \%)$ & $(30.7 \%)$ & $(8.8 \%)$ & $(7.7 \%)$ \\
$4 . \quad$ I like when someone & 47 & 34 & 9 & 1 \\
& gives me & $(51.7 \%)$ & $(37.4 \%)$ & $(9.9 \%)$ & $(1.1 \%)$ \\
& Book & & & & \\
\hline
\end{tabular}

Regarding the first statements of students' attitude towards reading from Table 1, 50.5\% of the respondents strongly agree that "Reading is enjoyable". Followed by $40.6 \%$ of the respondents who chose to agree. It means that students of English Language Education (ELE) responded positively to the first statement and agreed that reading English is an enjoyable activity.

The second statement is about "Reading is an interesting activity". It could be seen from Table 1, $49.5 \%$ of the respondents strongly agree. Followed by $31.8 \%$ of the respondents who chose agree to this second statement. Therefore, it can be said students responded positively and agreed reading is an interesting and fun activity.

The third statement is about "Attitude towards visiting library". From Table 1, there were $52.8 \%$ of the respondents who strongly agree and there were $30.7 \%$ of the respondents who chose agree. It showed a high percentage of students who responded positively and had a good attitude towards visiting libraries and borrowing books from the library. 
The last statement is about "Receiving books from someone". Students responded positively with this statement, there was a high percentage for about $51.7 \%$ of the respondents chose strongly agree and $37.4 \%$ chose agree. From this result, it means that students get support to read more from others and also it can expand their reading preference.

\subsubsection{Purpose on Reading Habits}

Table 2. Results of Students' Purpose on Reading

\begin{tabular}{clcccc}
\hline No. & \multicolumn{1}{c}{ Statements } & $\begin{array}{c}\text { Strongly } \\
\text { Agree }\end{array}$ & Agree & Disagree & $\begin{array}{c}\text { Strongly } \\
\text { Disagree }\end{array}$ \\
\hline 1. & I believe reading can improve my & 57 & 24 & 9 & 1 \\
& skills & $(80.2 \%)$ & $(13.2)$ & $(9.9 \%)$ & $(1.1 \%)$ \\
2. & I do not believe & 4 & 5 & 24 & 58 \\
& reading can improve my skills & $(4.4 \%)$ & $(5.5 \%)$ & $(26.4 \%)$ & $(63.7 \%)$ \\
3. & I read for personal & 48 & 28 & 8 & 7 \\
& satisfaction & $(52.7 \%)$ & $(30.8 \%)$ & $(8.8 \%)$ & $(7.7 \%)$ \\
4. & I read for school & 47 & 34 & 9 & 1 \\
& task & $(51.6 \%)$ & $(37.4 \%)$ & $(9.9 \%)$ & $(1.1 \%)$ \\
\hline
\end{tabular}

The data related to the first statements of purpose on reading habits is "I believe reading can improve my skills". Presented in Table 2, that students responded positively believing reading can improve their skills. The percentage showed that $80.2 \%$ of the respondents strongly agree. Meanwhile, the second statement that said "I do not believe reading can improve my skills" showed $63.7 \%$ of the respondents strongly disagree with this statement. It means, students believe by reading a book it can help to improve their English skills.

The third and fourth statements are about "Purpose to read for personal satisfaction or for school tasks". Most of the students responded positively towards this statement. The result Table 2 showed, there were $52.7 \%$ of the respondents who strongly agree reading is for personal satisfaction and there were $51.6 \%$ of the respondents also chose strongly agree they read for school tasks. It means, students already know their purpose for reading that by reading it can help them to improve their English skills or only for personal satisfaction and school tasks.

\subsubsection{Frequency on Reading}

Table 3. Results on Students' Frequency on Reading

\begin{tabular}{|c|c|c|c|c|c|}
\hline No. & Statements & $\begin{array}{c}\text { Strongly } \\
\text { Agree }\end{array}$ & Agree & Disagree & $\begin{array}{l}\text { Strongly } \\
\text { Disagree }\end{array}$ \\
\hline 1. & I read 1-2 hours / day & $\begin{array}{c}3 \\
(3.3 \%)\end{array}$ & $\begin{array}{c}19 \\
(20.9 \%)\end{array}$ & $\begin{array}{c}31 \\
(34.1 \%)\end{array}$ & $\begin{array}{c}38 \\
(41.8 \%)\end{array}$ \\
\hline 2. & I read 2-4 hours / day & $\begin{array}{c}38 \\
(41.8 \%)\end{array}$ & $\begin{array}{c}30 \\
(33 \%)\end{array}$ & $\begin{array}{c}17 \\
(18.7 \%)\end{array}$ & $\begin{array}{c}6 \\
(6.6 \%)\end{array}$ \\
\hline 3. & I read every weeks & $\begin{array}{c}38 \\
(41.8 \%)\end{array}$ & $\begin{array}{c}22 \\
(24.2 \%)\end{array}$ & $\begin{array}{c}20 \\
(22 \%)\end{array}$ & $\begin{array}{c}11 \\
(12.1 \%)\end{array}$ \\
\hline 4. & I read once in a month & $\begin{array}{c}7 \\
(7.7 \%)\end{array}$ & $\begin{array}{c}18 \\
(19.8 \%)\end{array}$ & $\begin{array}{c}30 \\
(33 \%)\end{array}$ & $\begin{array}{c}36 \\
(39.6 \%)\end{array}$ \\
\hline 5. & $\begin{array}{l}\text { I read less than five books / } \\
\text { month }\end{array}$ & $\begin{array}{c}36 \\
(39.6 \%)\end{array}$ & $\begin{array}{c}33 \\
(36.3 \%)\end{array}$ & $\begin{array}{c}14 \\
(15.4 \%)\end{array}$ & $\begin{array}{c}8 \\
(8.8 \%)\end{array}$ \\
\hline 6. & $\begin{array}{l}\text { I read more than five books / } \\
\text { month }\end{array}$ & $\begin{array}{c}5 \\
(5.5 \%) \\
\end{array}$ & $\begin{array}{c}8 \\
(8.8 \%) \\
\end{array}$ & $\begin{array}{c}40 \\
(44 \%) \\
\end{array}$ & $\begin{array}{c}38 \\
(41.8 \%) \\
\end{array}$ \\
\hline
\end{tabular}


Table 3 showed that when students were asked how many hours per day they spend on reading activities. The data showed that students positively chose strongly agree to spend more time on the average of $2-4$ hours per day. $41.8 \%$ of the respondents agree with this statement. It is believed that spending more time on reading will help improve their reading skills and reading habits. Agreeing with this result, therefore, $41.8 \%$ of the respondents strongly disagree with the statement "I read 1-2 hours per day".

Next, students were asked about the question when they read. The students strongly agree to the statement "I read a book every week", and about $39.6 \%$ of the respondents responded positively towards this statement. It means reading a book is very important for the students daily. Therefore, $39.6 \%$ of the respondents strongly disagree with the statement "I read a book once a month" because it will lose students' focus if reading is not part of their daily activity.

Majority of students English Language Education (ELE) chose strongly agree with the statement "I read less than five books every week", while 39.6\% of the respondents responded negatively to this statement. It is because students also have to share their time for other activities, for example doing their hobbies, quality time with family, etc. Moreover, $41.8 \%$ of the respondents strongly disagree with the statement" I read more than five books ever".

\subsubsection{Reading Preference}

Table 4. Results of Students' Reading Preference

\begin{tabular}{clcccc}
\hline No. & \multicolumn{1}{c}{ Statements } & $\begin{array}{c}\text { Strongly } \\
\text { Agree }\end{array}$ & Agree & Disagree & $\begin{array}{c}\text { Strongly } \\
\text { Disagree }\end{array}$ \\
\hline 1. & I only read & 10 & 34 & 35 & 12 \\
& fiction text & $(11 \%)$ & $(37.4 \%)$ & $(38.5 \%)$ & $(13.2 \%)$ \\
2. & I only read non- & 6 & 21 & 49 & 15 \\
& fiction text & $(6.6 \%)$ & $(23.1 \%)$ & $(53.8 \%)$ & $(16.5 \%)$ \\
\multirow{2}{*}{3.} & I have a lot of & 31 & 28 & 19 & 13 \\
& published writers & $(34.1 \%)$ & $(30.8 \%)$ & $(20.9 \%)$ & $(14.3 \%)$ \\
4. & I do not have any & 17 & 20 & 22 & 32 \\
& published writers & $(18.7 \%)$ & $(22 \%)$ & $(24.2 \%)$ & $(35.2 \%)$ \\
5. & I can get information & 53 & 29 & 6 & 3 \\
& using Internet & $(58.2 \%)$ & $(31.9 \%)$ & $(6.6 \%)$ & $(3.3 \%)$ \\
6. & I cannot get information & 12 & 13 & 26 & 40 \\
& using Internet & $(13.2 \%)$ & $(14.3 \%)$ & $(29 \%)$ & $(44 \%)$ \\
\hline
\end{tabular}

Based on the result from 6 statements above, $38.5 \%$ of the respondents chose to disagree with the statement "I only read fiction text". On the other hand, $53.8 \%$ of the respondents also disagreed with the statement "I only read non-fiction text". It could be said that students responded positively towards those two statements, because students not only read for a specific genre, they also like other genres to expand their reading preference.

To support their reading preference, the result on Table 4 showed $34.1 \%$ of the respondents strongly agree with the statement "I have a lot of published writers". This means students respond positively by having a lot of reference of published writers will help their eagerness to read more books. Therefore, $35.2 \%$ of the respondents strongly disagree with the statement "I do not have any published writers". 
The last statement for reading preference is the use of the Internet. There was a big percentage $58.2 \%$ of the respondents strongly agreed with the statement "I can get information using the Internet". It means that nowadays the majority of students can't live without the Internet, because the Internet is easier to access any sources of reading materials.

\subsection{Discussion}

\subsubsection{Attitude Towards Reading}

This study noticed that most of the respondents positively have attitudes towards reading. It means, by having a good attitude towards reading students can feel that reading is an enjoyable and interesting activity. They also agreed that their positive attitudes towards reading make them more enjoy visiting libraries and they have interest when receiving books from someone. Reading is basically a fun activity if it gets the right treatment. However, learning to read may be such a boring activity, especially for some students who often find failure in learning. For this reason, students must be motivated to practice reading more to build their reading habits. This is related to reading skills that cannot be obtained suddenly. Because in general, someone's reading skills can be obtained through learning step by step and continuously.

Moreover, Dewi (2018) also stated that learning English in class should be conducted effectively and fun. Creating fun learning and supportive family, teachers, and peers also play the main role in the success of the students and it will make the students fully focus on learning. In this regard, Yurdakal (2019) added that being a role model is especially important in changing students' attitudes toward reading. Families who read books at home, visit bookstores with their children, or exchange books would have a positive impact on their children's attitudes toward reading. The development of positive attitudes toward reading has been associated with sustained reading throughout the lifespan. While teachers often identify students' attitudes toward reading as critical, there was only a little time spent in schools cultivating positive reading attitudes. According to several reports, healthy readers have more positive attitudes toward reading than mediocre readers. In conclusion, not all poor readers dislike reading, however, many maintain positive reading attitudes despite limited skills and continuing frustration.

\subsubsection{Purpose on Reading Habits}

The majority of respondents read for pleasure and to improve their understanding of the language they were reading. Reading serves a variety of purposes, not only for students but also for the general public. To gain insight and awareness about social living, they must read extensively. It can assist a person in staying informed about his country's social, political, and economic issues. According to the second indicator, it was found that most of the respondents positively have a purpose in reading. It is proven that the respondents have various purposes in reading. They believe that by having a purpose in reading it can improve their English skills and help them to gain many advantages in life. This is supported by Lusianah (2017) who stated thus students' who have a purpose in reading habit helps them improve their ability in gaining academic purpose.

The respondents' purpose in reading is not only for personal satisfaction but also, they consider reading as an important element for school tasks and their further career. The finding 
from a previous study, Baba and Affendi (2020) highlighted that the majority of students at the Faculty of Education Puncak Alam Malaysia spend some time reading academically and leisurely on a regular basis for educational and recreational purposes. Reading is strongly linked to their academic success, which can have a huge impact on their future careers. As a result, students must develop their reading habits by reading in their spare time, especially English reading materials, because reading is one of the activities that can help us become better and more logical thinkers.

\subsubsection{Frequency on Reading}

The results from this indicator showed that most of the respondents positively have frequency on reading. The respondents agreed that reading for 2-4 hours per day and reading a book every week will help them to gain good reading habits. It is in line with Laddoo (2007) stating that spending more time in reading forces the reader's brain cells to work on a regular basis as this will keep the reader sharper and smarter.

However, the number of books that the respondents read showed they read less than five books every week. This was enough for them because they have to share their time with other activities such as quality time with family etc. In a previous study conducted by Sangkaeo (1999) stated that in terms of the types of reading materials consumed by university students, it was discovered that in their spare time, they read books, journals, and magazines. However, they are unable to devote much time to reading because they are preoccupied with classes, a busy social life, and computer use.

\subsubsection{Reading Preference}

According to the last indicator, it showed that the respondents positively have reading preference. From the result, most of the respondents agree that they read various genres of reading materials, such as fiction, novels, magazines, etc. Moreover, by having various kinds of genres the respondents claimed that they have a lot of published writers. While a study from Aptari (2019) added fiction is the most preferred genre chosen by female students. Romance and poetry are more popular among them. Similarly, male students are greater in non-fiction. Crime and mystery are the most read genres among males. Dewi (2018) explained, choosing books according to personal interests increases the level of motivation of students, encourages them to apply positive attitudes, and perform better. Dewi (2018) added, the reading interest itself not only comes from inside but also should be stimulated from outside simply from teachers and other facilities support like teaching materials, supplementary books, textbooks, etc. Furthermore, an effective understanding of the different genres that the students read requires a combination of word recognition ability, connecting new information to prior knowledge, and the use of appropriate strategies including locating the key concept, creating correlations, questioning, inferring, and predicting. As a result, selecting the material for the English reading text is not easy, which is why many students attempt to read a variety of genres.

In the last statement the respondents also agree that the use of the Internet will make it easier to search other reading references. In the Digital Era, Computers, laptops, and even cell phones have replaced printed media such as books, magazines, and newspapers. Students have instant access to an infinite amount of information due to the availability of technology and the help of an internet connection, which allows them to distribute generated information or ideas 
instantly (Aydin \& Ayranci, 2018). Furthermore, according to Bandele (2006), the growth of electronic media as a source of information and entertainment has been phenomenal. The number of people going wireless and using the Internet to gather information is increasing every day, particularly among youngsters.

\section{Conclusion}

Based on the data findings and discussion of the English reading habits of English Language Education (ELE) students of English Department, Universitas Negeri Malang presented several points which related to the research question. Overall, the students' reading habits from the fifth semester are good. It can be seen in each result of the questionnaire that the numbers of respondents tend to select both options of agree and strongly agree which means that they qualify to have high reading habits.

Through these reading habit activities, the students who received treatment from their parents, teachers, and peers at an early age are able to have a purpose in mind especially before they read English materials. It can encourage them to read actively. Generally, the students believe that reading can be effective in many aspects of their lives. They believe that reading can enhance and develop their English skills. In addition, the students also consider that reading can give aesthetic pleasure and see the unknown in the world to foster learning and prepare for the exam.

In this study, reading activities that the students have been doing from time to time will encourage them to have an attitude towards reading and make them think reading is such an interesting activity. Furthermore, students believe that reading enables them to express their feelings that reading is enjoyable. Therefore, the students' reading habits are beneficial to develop individual capacity, to express feeling and pleasure.

In relation to the reading preference of the students, the students like reading the books both from foreign authors and Indonesian authors. In addition, the students like various genres both fiction and non-fiction. From the data obtained, the researcher can conclude that the students tend to read topics that support their studies, either for academic purposes or for pleasure.

Finally, this study concludes that the students have developed good English reading habits, but they still need improvement especially in the frequency of practice in reading English books and the number of English books read. The age of young learners and adult learners make a difference in the outcome of reading frequency. Different genders also have their perspective towards how long time is spent reading.

It is suggested that teachers should motivate the students to read until the students feel confident in reading without getting any pressure. Through enjoyable reading, the students can get more knowledge that will be useful for students in their real life. For the students, considering the result of the study that the students already have a good reading habit. Literacy programs are very good for increasing student knowledge. It is more effective to improve students' reading habits. Implementing literacy programs every day can make students have good reading intensity. Reading more often will affect reading habits from bad to good and from good to better. Therefore, students should be aware of their reading habit and should know the importance of reading to increase their reading habit and it should be a priority. For further research, it is recommended for future researchers to carry out further research on 
similar topics. In addition, it is also suggested for future researchers to use these findings as an additional reference and as material for consideration in conducting further research.

\section{References}

Antari, D. N., Nenden, S., \& Neneng, S. R. (2016). Studi deskriptif minat baca siswa sekolah dasar kelas V di Kota Serang. Jurnal Kalimaya, 4(2).

Aptari, M. (2019). The relationship between students' reading habit and their reading comprehension at State Junior High School 14 Pekanbaru. (Doctoral dissertation, Universitas Islam Negeri Sultan Syarif Kasim Riau).

Aydin, G., \& Ayranci, B. B. (2018). Reading preferences of middle school students. World Journal of Education, 8(2), 127-139.

Baba, J., \& Affendi, F. R. (2020). Reading habits and students' attitudes towards reading: A study of students in the Faculty of Education UiTM Puncak Alam. Asian Journal of University Education, 16(1), 109-122.

Bandele, S. O. (2006). Development of ICT and internet systems, information and telecommunication systems. General Studies Unit. University of Ado-Ekiti.

Dewi, N.S. (2018). Students' reading preference and its implications: A study of three English Education Departments in Jember. Lingua Scientia, 25(2), 89-97.

Gaona, J. C. G., \& Villuendas, E. (2011). Relationship between reading habits, university library and academic performance in a sample of psychology students. Revista de la Educación superior, 15(157), 55-73.

Iftanti, E. (2012). A survey of the English reading habits of EFL students in Indonesia. TEFLIN Journal, 23(2), 149-164.

Laddoo, R. B. (2007). The importance of reading. Retrieved from http://www.squidoo. com/the-importanceof-reading.

Lestari, S., Latief, M. A., \& Widiati, U. (2017). The implementation of planning and its effect on EFL students' writing performance. Jurnal Ilmu Pendidikan, 22(1), 26-35.

Lusianah, N. (2017). Reading habit, vocabulary mastery and reading comprehension of secondary school students of Patra Mandiri. The Journal of English Literacy Education: The Teaching and Learning of English as a Foreign Language, 4(2), 132-146.

Noor, N. M. (2011). Reading habits and preferences of EFL postgraduates: A case study. Indonesian Journal of Applied Linguistics, 1(1), 1-9.

Putra, A. A. (2018). Exploring the reading habits of students of English Language Teaching Program (Doctoral dissertation, Universitas Negeri Malang).

Sangkaeo, S. (1999). Reading Habit Promotion in ASEAN Libraries. (Opinion paper). Retrieved from http://www.ifla.org/IV/ifla65/papers/091-114e.htm.

Shen, L. B. (2006). Computer technology and college students' reading habits. Chia-nan annual bulletin, 32, 559572.

Sugiyono, (2009). Metode Penelitian Kualitatif, Kuantitatif, dan R\&D, Bandung: Alfabeta.

Triatma, I. N. (2016). Minat baca pada siswa kelas VI Sekolah Dasar Negeri Delegan 2 Prambanan Sleman Yogyakarta. E-Jurnal Skripsi Program Studi Teknologi Pendidikan, 5(6), 166-178.

Yurdakal, I. H. (2019). Examination of correlation between attitude towards reading and perception of creative reading. European Journal of Educational Research, 8(2), 443-452.

Zulkarnain, R. S. (2019). The English Department freshmen's reading habit and their attitude toward reading. (Diploma thesis, Universitas Negeri Malang). 